\title{
Gene Pyramiding for Achieving Enhanced Resistance to Bacterial Blight, Blast, and Sheath Blight Diseases in Rice
}

\section{OPEN ACCESS}

Edited by:

Dayun Tao

Yunnan Academy of Agricultural

Sciences, China

Reviewed by:

Qinzhong Yang,

Yunnan Academy of Agricultural

Sciences, China

Tongmin Mou,

Huazhong Agricultural University,

China

*Correspondence: Jegadeesan Ramalingam ramalingam.j@tnau.ac.in

Specialty section:

This article was submitted to

Plant Breeding,

a section of the journal

Frontiers in Plant Science

Received: 04 August 2020 Accepted: 06 October 2020 Published: 19 November 2020

Citation:

Ramalingam J, Raveendra Ch, Savitha P, Vidya V, Chaithra TL, Velprabakaran S, Saraswathi $R$, Ramanathan A, Arumugam Pillai MP, Arumugachamy $S$ and Vanniarajan $C$ (2020) Gene Pyramiding for Achieving

Enhanced Resistance to Bacterial Blight, Blast, and Sheath Blight

Diseases in Rice.

Front. Plant Sci. 11:591457. doi: 10.3389/fp/s.2020.591457

\author{
Jegadeesan Ramalingam ${ }^{1,2 *}$, Chandavarapu Raveendra ${ }^{1,3}$, Palanisamy Savitha ${ }^{2}$, \\ Venugopal Vidya ${ }^{2}$, Thammannagowda Lingapatna Chaithra², \\ Senthilvel Velprabakaran 1,3, Ramasamy Saraswathi ${ }^{4}$, Ayyasamy Ramanathan ${ }^{5}$, \\ Madhavan Pillai Arumugam Pillai ${ }^{6}$, Samudrakani Arumugachamy ${ }^{7}$ and \\ Chockalingam Vanniarajan ${ }^{3}$
}

\begin{abstract}
${ }^{1}$ Centre of Excellence for Innovations, Department of Biotechnology, Agricultural College and Research Institute, Tamil Nadu Agricultural University, Madurai, India, ${ }^{2}$ Centre for Plant Molecular Biology and Biotechnology, Tamil Nadu Agricultural University, Coimbatore, India, ${ }^{3}$ Department of Plant Breeding and Genetics, Agricultural College and Research Institute, Tamil Nadu Agricultural University, Madurai, India, ${ }^{4}$ Department of Rice, Centre for Plant Breeding and Genetics, Tamil Nadu Agricultural University, Coimbatore, India, ${ }^{5}$ Tamil Nadu Rice Research Institute, Tamil Nadu Agricultural University, Aduthurai, India, ${ }^{6}$ Agricultural College and Research Institute, Tamil Nadu Agricultural University, Killikulam, India, ${ }^{7}$ Rice Research Station, Tamil Nadu Agricultural University, Ambasamudram, India
\end{abstract}

Bacterial blight, blast, and sheath blight are the commonest diseases causing substantial yield loss in rice around the world. Stacking of broad-spectrum resistance genes/QTLs into popular cultivars is becoming a major objective of any disease resistance breeding program. The varieties ASD 16 and ADT 43 are the two popular, high yielding, and widely grown rice cultivars of South India, which are susceptible to bacterial blight (BB), blast, and sheath blight diseases. The present study was carried out to improve the cultivars (ASD 16 and ADT 43) through introgression of bacterial blight (xa5, xa13, and Xa21), blast (Pi54), and sheath blight ( $q S B R 7-1, q S B R 11-1$, and qSBR11-2) resistance genes/QTLs by MABB (marker-assisted backcross breeding). IRBB60 (xa5, xa13, and Xa21) and Tetep (Pi54; qSBR7-1, qSBR11-1, and qSBR11-2) were used as donors to introgress $\mathrm{BB}$, blast, and sheath blight resistance into the recurrent parents (ASD 16 and ADT 43). Homozygous $\left(\mathrm{BC}_{3} \mathrm{~F}_{3}\right.$ generation), three-gene bacterial blight pyramided $(x a 5+x a 13+$ Xa21) lines were developed, and these lines were crossed with Tetep to combine blast (Pi54) and sheath blight (qSBR7-1, qSBR11-1, and qSBR11-2) resistance. In $\mathrm{BC}_{3} \mathrm{~F}_{3}$ generation, the improved pyramided lines carrying a total of seven genes/QTLs $(x a 5+x a 13+$ Xa21 + Pi54 + qSBR7-1 + qSBR11-1 + qSBR11-2) were selected through molecular and phenotypic assay, and these were evaluated for resistance against bacterial blight, blast, and sheath blight pathogens under greenhouse conditions. We have selected nine lines in ASD 16 background and 15 lines in ADT 43 background, exhibiting a high degree of resistance to BB, blast, and sheath blight diseases and also possessing phenotypes of recurrent parents. The improved pyramided lines are expected to be used as improved varieties or used as a potential donor in breeding programs. The present study successfully 
introgressed Pi54, and qSBR QTLs (qSBR7-1, qSBR11-1, and qSBR11-2) from Tetep and major effective BB-resistant genes (xa5, xa13, and Xa21) from IRBB60 into the commercial varieties for durable resistance to multiple diseases.

Keywords: rice, multiple disease resistance, marker-assisted backcross breeding, gene pyramiding, phenotyping

\section{INTRODUCTION}

Rice (Oryza sativa L.) is considered a major staple food crop for billions of population across the globe, and it provides $23 \%$ of calories shared by different food crops (Sharma et al., 2012). Exponential growth of the world population demands an increase in rice production by $26 \%$ to fulfill calorie requirements (Khush, 2013). According to the Food and Agricultural Organization, the global rice production would have to increase by $42 \%$ over the present-day production to meet the growing population by 2050 (Ray et al., 2013). However, the yield potential is frequently threatened by various biotic stresses, mostly fungi, and bacteria. To address these problems and to increase production, developing cultivars with durable resistance is a prerequisite. The host-plant resistance can be ideally improved through pyramiding of major $R$-genes/QTLs for multiple diseases and biotic stress factors.

Bacterial blight $(\mathrm{BB})$ caused by Xanthomonas oryzae pv. oryzae $(X o o)$ is a major destructive disease of rice, causing a yield loss of up to $80 \%$ depending on the severity (Kumar et al., 2012). Improving the host-plant resistance is the most efficient and ecofriendly approach, as chemical control of BB is not effective (Lee et al., 2003). The infection chain starts by entering into the plant through the hydathodes, and it reaches to xylem vessels, where the infection became systemic. Till date, 46 resistance genes have been identified from the different sources of rice (Chen et al., 2020). Of these, the Xa4, Xa5, Xa7, xa13, Xa21, Xa33, and $\mathrm{Xa38}$ genes are most frequently utilized in hybridization programs for developing BB-resistant cultivars (Hsu et al., 2020). Natural allelic variations in Xoo challenges the resistance levels conferred by a single gene; hence, pyramiding of two or more effective resistance genes is highly essential for broad-spectrum and durable resistance to Xoo at field conditions. Xa21, a major dominant resistant gene, originated from African wild species, Oryza longistaminata, was observed to confer the resistance to many Xoo isolates (Nguyen et al., 2018). The encoding proteins of Xa21 gene carries both leucine-rich repeats (LRR) and serinethreonine kinases, and these complexes perceives the presence of pathogen ligand on the cell surface and activates the subsequent intracellular defense response $R$-proteins (Song et al., 1995). The Xa21 gene was physically mapped on the long arm of chromosome 11, and a highly efficient PCR-based co-dominant molecular marker (pTA 248) was developed for marker-assisted selection of Xa21 (Ronald et al., 1992). A unique, fully recessive gene, xa13, was first identified in cultivar BJ1 and physically mapped on the long arm of chromosome 8 (Zhang et al., 1996). Mutations in the promoter region of dominant allele (Xa13) resulted in a recessive gene, xa13, which does not encode for a modulator for pathogen ( $\mathrm{Chu}$ et al., 2006). Another broadspectrum recessive resistant gene, $x a 5$, was identified and mapped on the subtelomeric region of chromosome number 5 (Blair et al., 2003). Unlike other $R$-genes, the $x a 5$ gene encodes for a gamma transcription factor-like protein (TFIIA $\gamma$ ). Pyramiding of xa5 gene with other dominant genes gives durable resistance to Xoo than the plants with single BB-resistant gene (Huang et al., 1997).

Rice blast, caused by Magnaporthe oryzae (Teleomorph: Pyricularia oryzae), is one of the devastating diseases of rice growing areas across the world. Yield loss is estimated to be more than $50 \%$ when it occurs in epidemic proportions (Babujee and Gnanamanickam, 2000). Similar to BB, developing of hostplant resistance is the most effective strategy for management of blast disease (Sharma et al., 2012). So far, about 100 resistance genes have been identified, and 37 of them were cloned (Zhang et al., 2019). Although several blast resistance genes have been identified, only a few of them were used in breeding programs for blast disease management in India (Singh et al., 2011). Among them, the Pi54 gene located on chromosome 11 provides stable and durable resistance to diverse strains of $M$. oryzae collected across India (Thakur et al., 2015). The predicted proteins of the Pi54 gene contains NBS-LRR proteins along with unique zinc finger domain (Sharma et al., 2005). During the hostpathogen interaction, the Pi54 gene induces the synthesis of callose ( $\beta$-1,3-glucan), which acts as a physical barrier by blocking the penetration of fungal hyphae (Gupta et al., 2012). A functional marker has been developed for the Pi54 gene and used in maker-assisted selection for developing blast-resistant cultivars (Ramkumar et al., 2011).

Rhizoctonia solani Kühn, the causative agent of rice sheath blight disease $(\mathrm{ShB})$, poses a significant impact on both yield and quality (Singh et al., 2019). Introduction of high yielding varieties and application of high doses of nitrogenous fertilizers resulted in a steep rise in incidence of sheath blight disease (Savary et al., 1997). R. solani Kühn is a soil-borne facultative parasite, survives as sclerotia or mycelium, or rarely as basidiospores. No varieties resistant to sheath blight were reported till date (Channamallikarjuna et al., 2010). Breeding for resistance to ShB is quite unsuccessful owing to inability to identify effective resistance sources from the available germplasm, wide-ranging host compatibility, high genetic variability, and capability of the pathogen to survive from season to season in the form of dormant sclerotia, makes additional complications in controlling the disease (Molla et al., 2020). Though qualitative resistance to $\mathrm{ShB}$ was not found, quantitative resistance was reported in some landraces viz., Tetep, Teqing, Jasmine 85, etc., (Channamallikarjuna et al., 2010; Wang et al., 2012; Yadav et al., 2015). Up to now, 50 QTLs conferring moderate resistance to rice sheath blight have been identified from the different sources of rice (Zhang et al., 2019). Among these, qSBR7-1, $q S B R 11-1$, and $q S B R 11-2$ were identified in the background of Tetep (Channamallikarjuna et al., 2010) and pyramided in 
Pusa 6B (Singh et al., 2015). We have used these three QTLs (qSBR7-1, qSBR11-1, and qSBR11-2) for pyramiding in our recurrent parents to improve sheath blight resistance.

In cognizance of the above reports, the present study was formulated with the following objectives: (i) introgression of BB ( $x a 5, x a 13$, and Xa21), blast (Pi54), and sheath blight (qSBR7-1, qSBR11-1, and qSBR11-2) resistance genes/QTLs in the backgrounds of ASD 16 and ADT 43; (ii) analysis of recurrent parent genome recovery (RPG) with a set of polymorphic SSR (simple sequence repeats) markers; (iii) evaluation of improved pyramided lines for physical resistance against $\mathrm{BB}$, blast, and sheath blight diseases; and (iv) evaluation of agro-morphological and quality traits of improved pyramided lines in comparison with parents.

\section{MATERIALS AND METHODS}

\section{Plant Materials}

The two recurrent parents, ASD $16(\mathrm{ADT} 31 \times \mathrm{CO} 39)$ and ADT 43 (IR $50 \times$ Improved White Ponni) are popular, high yielding, and widely grown rice cultivars of South India. ASD 16 has short bold grains, while ADT 43 has medium slender fine grains. Though both cultivars are high yielding, they are highly susceptible to BB, blast, and sheath blight diseases. A bacterial blight-resistant genotype, IRBB60 harboring $x a 5+x a 13+X a 21$ was used as donor for BB resistance genes. Tetep, a Vietnamese indica land race possessing blast resistance (Pi54) (Ramkumar et al., 2011) and moderately resistant to sheath blight, harboring qSBR QTLs (qSBR7-1, qSBR11-1, and qSBR11-2) (Channamallikarjuna et al., 2010) was also used as one of the donors for targeted transfer of blast and sheath blight resistance into the background of recurrent parents (ASD 16 and ADT 43).

\section{Marker-Assisted Backcross Breeding for Targeted Gene/QTL Pyramiding of Bacterial Blight, Blast, and Sheath Blight in the Backgrounds of ASD 16, and ADT 43}

Two independent crosses $(\mathrm{ASD} 16 \times \mathrm{IRBB} 60$ and ADT $43 \times$ IRBB60) were made between recipient parents and IRBB60 for targeted gene transfer of $x a 5, x a 13$, and Xa21. The hybridity of the $F_{1}$ plants were confirmed by functional/linked PCRbased co-dominant molecular markers of $x a 5, x a 13$, and Xa21 (Table 1). The heterozygous plants for $x a 5, x a 13$, and Xa21 were backcrossed with respective recurrent parents (ASD 16 and $\mathrm{ADT} 43)$ to generate $\mathrm{BC}_{1} \mathrm{~F}_{1}$. The $\mathrm{BC}_{1} \mathrm{~F}_{1}$ hybrids were screened for targeted genes ( $x a 5, x a 13$, and Xa21), and the confirmed plants were assessed with a set of polymorphic SSR markers to recover the maximum percentage of RPG (Sundaram et al., 2008). The solitary plant with targeted genes ( $x a 5, x a 13$, and $\mathrm{Xa21}$ ) and maximum recovery of RPG was selected and backcrossed to generate $\mathrm{BC}_{2} \mathrm{~F}_{1}$, and this procedure was repeated till $\mathrm{BC}_{3} \mathrm{~F}_{1}$. At every backcross, foreground and background selections were carried out to forward the plant with targeted genes and maximum recovery of RPG. Pedigree-based breeding strategy with marker-assisted selection was followed after $\mathrm{BC}_{3} \mathrm{~F}_{1}$ to generate $\mathrm{BC}_{3} \mathrm{~F}_{2}$ and $\mathrm{BC}_{3} \mathrm{~F}_{3}$ populations. In $\mathrm{BC}_{3} \mathrm{~F}_{2}$ population, the homozygous plants for targeted genes were identified through foreground selection and self-pollinated to generate $\mathrm{BC}_{3} \mathrm{~F}_{3}$ population. The homozygous plants at $\mathrm{BC}_{3} \mathrm{~F}_{3}$ were evaluated for resistance against $\mathrm{BB}$ as well as for key agronomic traits, and the best lines were pooled to generate three-gene bacterial blight $(x a 5, x a 13$, and Xa21) pyramided lines of ASD 16, and ADT 43. The three-gene bacterial blight pyramided lines were crossed with Tetep to introgress blast and sheath blight resistance. The plants showing heterozygous allele for all the targeted genes/QTLs were backcrossed with respective recurrent parent (three-gene bacterial blight pyramided lines of ASD 16 and ADT 43) to generate $\mathrm{BC}_{1} \mathrm{~F}_{1}$. The $\mathrm{BC}_{1} \mathrm{~F}_{1}$ hybrids were screened with molecular markers for all the targeted traits in the study (Table 1) followed by background selection with polymorphic SSR markers. The "positive" plants with maximum recovery of $\mathrm{RPG}$ were again backcrossed with recurrent parents to produce $\mathrm{BC}_{2} \mathrm{~F}_{1}$ and $\mathrm{BC}_{3} \mathrm{~F}_{1}$. In the $\mathrm{BC}_{3} \mathrm{~F}_{2}$ population, foreground selection was carried out to identify the plants carrying all the targeted genes $(x a 5+x a 13+X a 21+P i 54)$ and targeted QTLs (qSBR7-1 + qSBR11-1 + qSBR11-2) in homozygous condition, and the identified plants were selfpollinated to generate $\mathrm{BC}_{3} \mathrm{~F}_{3}$ population. The plants carrying all the targeted traits in homozygous condition at $\mathrm{BC}_{3} \mathrm{~F}_{3}$ generation were evaluated for resistance against bacterial blight, blast, and sheath blight diseases under greenhouse conditions and also assessed for key agronomic as well as grain quality traits. The detailed plan of program for marker-assisted gene pyramiding of bacterial blight, blast, and sheath blight resistance genes/QTLs is depicted in Figure 1.

\section{DNA Extraction and PCR Amplification}

The DNA extraction for PCR amplification was carried out by the CTAB method (Varghese et al., 1997). The PCR protocol for marker-assisted selection of targeted genes/QTLs was followed according to the earlier reports (Chu et al., 2006; Iyer-Pascuzzi and McCouch, 2007; Sundaram et al., 2008; Channamallikarjuna et al., 2010; Ramkumar et al., 2011; Table 1). Ten microliters of PCR reaction mixture contains $4 \mu \mathrm{l}$ of DreamTaq green $2 \times$ PCR master mix (Thermo scientific, United States), $4 \mu 1$ of water, $50 \mathrm{ng}$ of template DNA, and $30 \mathrm{ng}$ each of forward and reverse primers. To find the specific allelic pattern of xa5 allele, 5-10 $\mu \mathrm{l}$ of PCR product is digested with BsrI (5 units of enzyme) at $65^{\circ} \mathrm{C}$ for $4 \mathrm{~h}$ with $2 \mu \mathrm{l}$ of $10 \times$ PCR buffer (IyerPascuzzi and McCouch, 2007). The amplified PCR products were separated by $2.5 \%$ agarose gel stained with ethidium bromide and visualized on UV light in gel documentation system (BioRad Laboratories., United States). Background selection was carried out with a set of 463 SSR $^{\text {markers }}{ }^{1} ; 69$ and 68 markers were found to be polymorphic for ADT 43 and ASD 16 cross combinations, respectively (Supplementary Table S1), with a wide coverage of all the 12 chromosomes (five to six polymorphic

\footnotetext{
${ }^{1}$ https://archive.gramene.org/
} 
TABLE 1 | Details of molecular markers used for foreground selection.

\begin{tabular}{|c|c|c|c|c|c|c|}
\hline Gene/QTL & Marker & Sequence $\left(5^{\prime}-3^{\prime}\right)$ & AT $\left({ }^{\circ} \mathbf{C}\right)$ & Chr & $\begin{array}{l}\text { Resistant } \\
\text { allele size (bp) }\end{array}$ & Reference \\
\hline Xa21 & pTA248 & $\begin{array}{l}\text { F-AGACGCGGAAGGGTGGTITCCCGGA } \\
\text { R-AGACGCGGTAATCGAAAGATGAAA }\end{array}$ & 65 & 11 & 925 & Ronald et al. (1992) \\
\hline xa13 & xa13-prom & $\begin{array}{l}\text { F-GAGCTCCAGCTCTCCAAATG } \\
\text { R-GGCCATGGCTCAGTGTITAT }\end{array}$ & 59 & 8 & 500 & Chu et al. (2006) \\
\hline xa5 & xa5-1 & $\begin{array}{l}\text { F-CTCTACCGGAGGTCCACCATTG } \\
\text { R-AGGAACAGCAACATTGCAAC }\end{array}$ & 53 & 5 & 299 & Iyer-Pascuzzi and McCouch (2007) \\
\hline Pi54 & Pi54-MAS & $\begin{array}{l}\text { F-CAATCTCCAAAGTITCAGG } \\
\text { R-GCTTCAATCACTGCTAGACC }\end{array}$ & 56 & 11 & 216 & Ramkumar et al. (2011) \\
\hline qSBR7-1 & RM336 & $\begin{array}{l}\text { F-CTTACAGAGAAACGGCATCG } \\
\text { R-GCTGGTITITTCAGGTCG }\end{array}$ & 55 & 7 & 190 & Channamallikarjuna et al. (2010) \\
\hline qSBR11-1 & RM224 & $\begin{array}{l}\text { F-ATCGATCGATCTTCACGAGG } \\
\text { R-TGCTATAAAAGGCATTCGGG }\end{array}$ & 55 & 11 & 130 & \\
\hline qSBR11-2 & RM209 & $\begin{array}{l}\text { F-ATATGAGTTGCTGTCGTGCG } \\
\text { R-CAACTTGCATCCTCCCCTCC }\end{array}$ & 55 & 11 & 150 & \\
\hline
\end{tabular}

markers per chromosome). Additional polymorphic markers, i.e., 10 polymorphic markers were employed on chromosome number 11, which carries Xa21, Pi54, qSBR11-1, and qSBR11-2 to minimize the linkage drag.

\section{Bioassays Against Bacterial Blight, Blast, and Sheath Blight Diseases Bacterial Blight}

The selected IPLs (improved pyramided lines) and parents (IRBB60 as resistant check and ASD 16 and ADT 43 as susceptible checks) were tested for resistance against the DX-027 of Xoo isolate under greenhouse conditions. In addition to the selected IPLs, single- and two-gene BB pyramided lines were also evaluated to check the effectiveness of three-gene BB pyramided lines. Three replications were maintained with 30 plants per replication. The top leaves were clipped off, and bacterial suspension was inoculated with a density of $10^{9}$ cells $/ \mathrm{ml}$ by clip inoculation method at maximum tillering stage (Kauffman et al., 1973). Eight leaves per plant were inoculated, and mean lesion length was taken on six leaves to measure the accurate disease reaction. Symptoms were measured 21 days post-inoculation, and observations were recorded based on visual score and lesion length (LL). The plants with an average lesion length of $<5 \mathrm{~cm}$ were considered as resistant, and those with $>5 \mathrm{~cm}$ were considered as susceptible (International Rice Research Institute [IRRI], 2002).

\section{Blast}

The IPLs and parents (Tetep as resistant check; ASD 16 and ADT 43 as susceptible checks) were evaluated for leaf blast resistance against IS (KUL)-6, a virulent local isolate of $M$. oryzae. Fiveweek-old seedlings were individually transplanted into mud pots $(19 \mathrm{~cm} \times 22 \mathrm{~cm} \times 22 \mathrm{~cm})$ with three replications and inoculated with $M$. oryzae IS (KUL)- 6 isolate at a spore density of $5 \times 10^{5}$ spores $/ \mathrm{ml}$. Disease reaction was recorded 9 days post-inoculation and evaluated based on blast lesion type (BLT) according to the 0-9 scale of SES (Standard Evaluation System) (International Rice Research Institute [IRRI], 2002). The plants with a score of 0-3 were rated as resistant and those with more than a score of 4 were rated as susceptible.

\section{Sheath Blight}

A pure culture of $R$. solani collected from the Tamil Nadu Rice Research Institute (TRRI), Aduthurai, Tamil Nadu, India, was used for testing the resistance of IPLs and parents against sheath blight. The pathogen was multiplied on sterilized shoot bits of water sedge, Typha angustata. Infected Typha shoot bits with mycelium and sclerotia were used as source of inoculum and placed carefully between the tillers of rice hills with the help of forceps at 80 days after sowing. The inoculated portion was covered with wet cotton and aluminum foil to avoid the moisture loss in the inoculated portion. The observations were recorded 25 days post-inoculation on randomly selected plants consisting of three infected tillers in each of three replications. Disease reaction was measured based on RLH\% (relative lesion height), and scoring (0-9) was given as per SES (International Rice Research Institute [IRRI], 2002) [0 (immune), 1-20\% (resistant), $21-30 \%$ (moderately resistant), 31-45\% (moderately susceptible), 46-65\% (susceptible), and $>65 \%$ (highly susceptible)].

\section{Characterization of Agro-Morphological and Quality Traits}

The 30-day old seedlings of recurrent parents and selected IPLs were transplanted to an experimental plot at the Agricultural College and Research Institute, Tamil Nadu Agricultural University, Madurai, India, with a spacing of $15 \mathrm{~cm} \times 20 \mathrm{~cm}$. The experimental plot was arranged in a randomized block design (RBD) with four blocks, and three replications were maintained in each block. Standard agronomic practices were followed as prescribed by TNAU, Coimbatore, India ${ }^{2}$, to raise the healthy crop. Observations were recorded on five plants in each line for key agronomic traits viz., days to 50\% flowering (DFF), plant height $(\mathrm{PH})(\mathrm{cm})$, number of productive tillers per plant (NPT), panicle length $(\mathrm{PL})(\mathrm{cm})$, number of grains per panicle (NGP),

${ }^{2}$ http://agritech.tnau.ac.in/ 


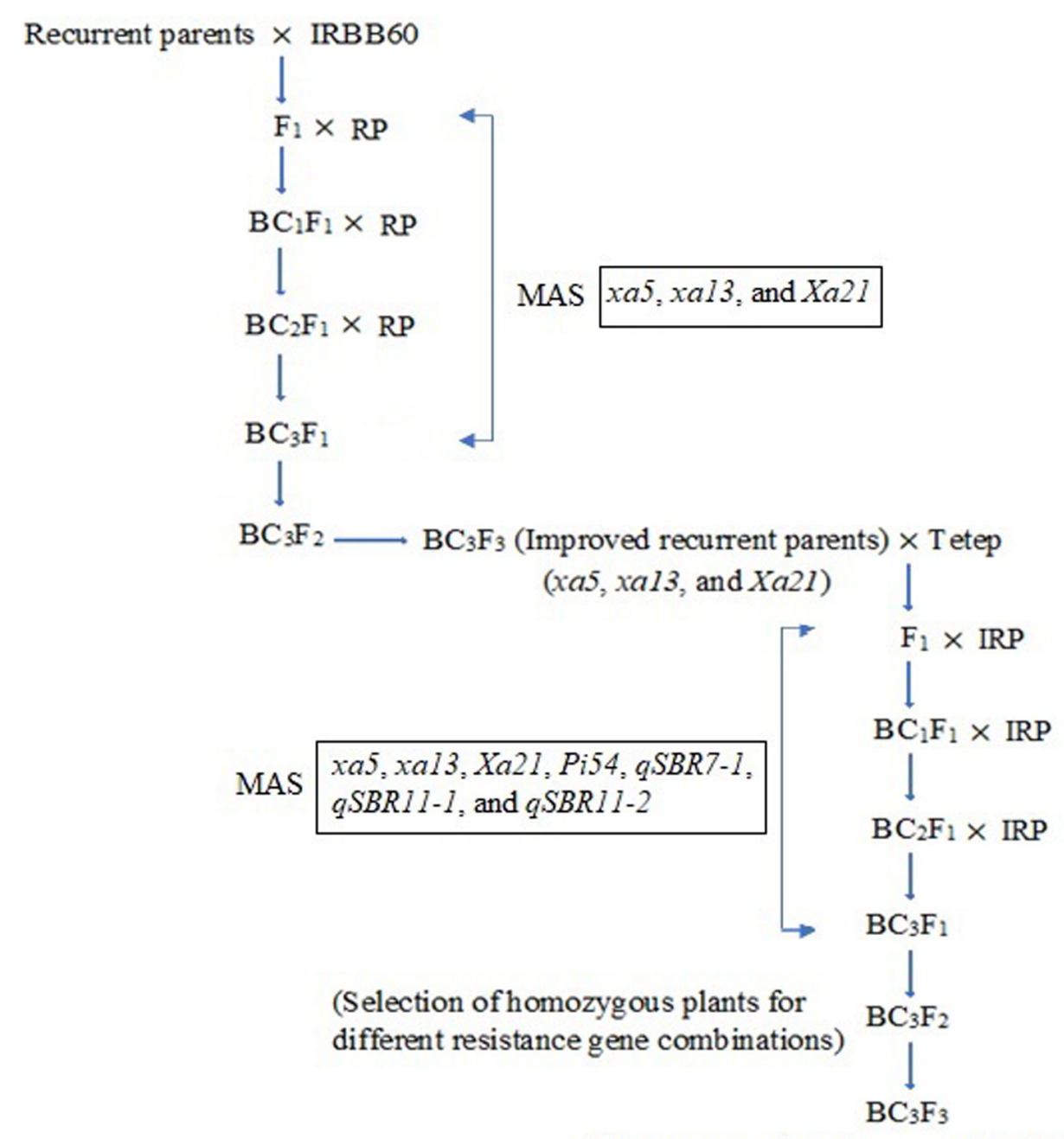

(Homozygous plants introgressed with $\mathrm{BB}$, blast, and sheath blight resistance genes/QTLs)

FIGURE 1 | Schematic illustration of marker-assisted gene pyramiding of bacterial blight, blast, and sheath blight resistance genes/QTLs in the backgrounds of ASD 16 and ADT 43. RP, recurrent parents (ASD 16 and ADT 43), IRP, improved recurrent parents (ASD 16 and ADT 43 introgressed with xa5, xa13, and Xa21 genes); MAS, marker-assisted selection.

flag leaf length $(\mathrm{FL})(\mathrm{cm})$, flag leaf width $(\mathrm{FW})(\mathrm{cm}), 1,000-$ grain weight $(1,000-\mathrm{GW})(\mathrm{g})$, grain-L/B ratio $(\mathrm{cm})$, and single plant yield (SPY) (g). In addition, the quality traits viz., hulling percentage (HP\%), milling percentage (MP\%), head rice recovery (HRR\%), kernel length (KL) (mm), kernel breadth (KB) (mm), kernel length breadth ratio (KLBR), milled rice length (MRL) $(\mathrm{mm})$, milled rice breadth (MRB) (mm), kernel length after cooking (KLAC) (mm), kernel breadth after cooking (KBAC) $(\mathrm{mm})$, and linear elongation ratio (LER) were analyzed in the homozygous improved pyramided lines.

\section{Statistical Analysis}

Statistical analysis was done with SPSS software to complement the ANOVA (analysis of variance) to determine the significant variation among the improved pyramided lines. The coefficient of genetic distance among the selected pyramided lines and parents was calculated based on 10 morphological characters and used for generating the dendrogram using the "R" software (R Core Team, 2013).

\section{RESULTS}

\section{Marker-Aided Pyramiding of Xa21, xa13, and $x a 5$ in the Backgrounds of ASD 16 and ADT 43}

The hybrids $\left(\mathrm{F}_{1}\right)$ from the crosses of ASD $16 \times$ IRBB60 and ADT $43 \times$ IRBB60 were analyzed with functional/linked molecular markers of $x a 5, x a 13$, and Xa21, i.e., $x a 5-1, x a-13$ prom and pTA 248 , respectively. A total of $12 / 138$ plants in ASD $16 \times$ IRBB60 cross combination and 15/157 plants in ADT 
$43 \times$ IRBB60 cross combination were found to be "positive" for all the targeted genes ( $x a 5, x a 13$, and Xa21). These positive plants were backcrossed with respective recurrent parents (ASD 16 and $\mathrm{ADT} 43$ ) to generate the $\mathrm{BC}_{1} \mathrm{~F}_{1}$ population. We have found that 9/134 plants in ASD 16 background and 13/150 plants in ADT 43 background were heterozygous for xa5, xa13, and $X a 21$, and these plants were screened with polymorphic SSR markers to assess the recovery of RPG. Background assay revealed that three plants in ASD 16 combination viz., IL-1-2-2, IL-1-5-6, and IL-1-8-18 with an RPG\% recovery of 75.60, 76.82, and 76.56, respectively, and two plants in ADT 43 combination viz., IL-2-1-33 and IL-2-2-53 with a recovery of $77.08 \%$ and 76.04\% were identified (Supplementary Table S2). These plants were backcrossed alone with respective recurrent parents to produce $\mathrm{BC}_{2} \mathrm{~F}_{1}$. In $\mathrm{BC}_{2} \mathrm{~F}_{1}, 10 / 154$ plants in ASD 16 background and 12/166 plants in ADT 43 background were found to be heterozygous for the targeted genes. In these $\mathrm{BC}_{2} \mathrm{~F}_{1}$ populations, we have identified two plants in ASD 16 combination and three plants in ADT 43 combination with background genome recovery ranging from 87.5 to $89.02 \%$ (Supplementary Table S2), and these plants were backcrossed to produce $\mathrm{BC}_{3} \mathrm{~F}_{1}$. In $\mathrm{BC}_{3} \mathrm{~F}_{1}$, we have found that 11/92 in ASD 16 background and 17/110 in ADT 43 background were shown to be triple heterozygous, and background assay indicates that three plants with RPG recovery ranged from 93.85 to $94.96 \%$ in ASD 16 combination, and two plants with a recovery of $94.26 \%$ and $94.04 \%$ were observed in ADT 43 combination (Supplementary Table S2). Self-pollination was carried out in the selected plants to generate $\mathrm{BC}_{3} \mathrm{~F}_{2}$ followed by $\mathrm{BC}_{3} \mathrm{~F}_{3}$. Homozygous plants for $x a 5$, xa13, and $\mathrm{Xa21}$ with key agro-morphological traits were identified through genotypic and phenotypic assays, and the best lines (six lines in ASD 16 combination and nine lines in the ADT 43 combination) were constituted to generate triple-gene (xa5, xa13, and Xa21) pyramided lines of ASD 16 and ADT 43 for bacterial blight resistance.

\section{Combining Multiple Disease (BB, Blast, and Sheath Blight) Resistant Genes/QTLs in the Backgrounds of ASD 16, and ADT 43}

The three-gene bacterial blight ( $x a 5, x a 13$, and $X a 21)$ pyramided lines of ASD 16 and ADT 43 were used as recipient parents for the targeted introgression of blast (Pi54) and sheath blight QTLs (qSBR7-1, qSBR11-1, and qSBR11-2) from the Tetep. The bacterial blight pyramided lines of ASD 16 and ADT 43 harboring xa5, xa13, and Xa21 were crossed with Tetep, and the $F_{1}$ plants were analyzed for all the targeted traits (Table 1). The hybrids with $x a 5+x a 13+X a 21+P i 54+q S B R 7-1+q S B R 11-1+q S B R 11-2$ in heterozygous condition were selected and backcrossed with ASD 16 and ADT 43 introgressions with the three-gene bacterial blight genes $(x a 5, x a 13$, and $\mathrm{Xa21})$ to recover the original RPG. $\mathrm{Up}$ to $\mathrm{BC}_{3} \mathrm{~F}_{1}$, all the foreground and background selections were made similar to pyramiding of bacterial blight-resistant genes, as explained above. Foreground selection of $\mathrm{BC}_{3} \mathrm{~F}_{1}$ hybrids revealed five plants in ASD 16 background and seven plants
TABLE 2 | Phenotypic reaction and disease score of improved pyramided lines against bacterial blight (BB), blast, and sheath blight diseases.

\begin{tabular}{|c|c|c|c|c|c|}
\hline \multirow[t]{2}{*}{ Genotype } & \multicolumn{2}{|c|}{ Bacterial blight } & \multirow{2}{*}{$\begin{array}{l}\text { Blast } \\
\text { Score }\end{array}$} & \multicolumn{2}{|c|}{ Sheath blight } \\
\hline & LL (cm) & Score & & RLH (\%) & Score \\
\hline ACM 18243 & $3.15 \pm 0.56$ & 0 & 2 & 44 & 5 \\
\hline ACM 18244 & $3.28 \pm 0.67$ & 0 & 1 & 28 & 3 \\
\hline ACM 18242 & $3.17 \pm 1.43$ & 1 & 1 & 39 & 5 \\
\hline ACM 18245 & $3.35 \pm 1.02$ & 1 & 3 & 30 & 3 \\
\hline ACM 18249 & $3.67 \pm 0.62$ & 0 & 1 & 37 & 5 \\
\hline ACM 18012 & $4.03 \pm 0.34$ & 1 & 2 & 43 & 5 \\
\hline ACM 18014 & $3.87 \pm 0.34$ & 0 & 1 & 38 & 5 \\
\hline ACM 18015 & $3.36 \pm 0.70$ & 0 & 0 & 29 & 3 \\
\hline ACM 18023 & $3.33 \pm 0.78$ & 1 & 1 & 35 & 5 \\
\hline ACM 18020 & $4.21 \pm 0.49$ & 1 & 2 & 30 & 3 \\
\hline IRBB60 & $3.10 \pm 0.45$ & 0 & - & - & - \\
\hline Tetep & - & - & 0 & 28 & 3 \\
\hline ASD 16 & $15.12 \pm 1.46$ & 9 & 9 & 78 & 9 \\
\hline ADT 43 & $16.88 \pm 0.56$ & 9 & 9 & 72 & 9 \\
\hline
\end{tabular}

$L L$, lesion length;

$R L H(\%)$, relative lesion height expressed in percentage;

$B B$ - $L L$ of $<5 \mathrm{~cm}$ is considered as resistant, and $L L>5 \mathrm{~cm}$ is considered as susceptible.

Blast - 0-1 (highly resistant), 2-3 (resistant), 4 (moderately resistant), 5-6 (moderately susceptible), 7 (susceptible), and 8-9 (highly susceptible).

Sheath blight - 0 (Immune), 1 (resistant), 3 (moderately resistant), 5 (moderately susceptible), 7 (susceptible), and 9 (highly susceptible).

in ADT 43 background possessing all the targeted genes and QTLs $(x a 5+x a 13+X a 21+$ Pi54 + qSBR7-1 + qSBR11$1+q S B R 11-2)$ in heterozygous condition. Background selection of these positive plants revealed two plants with RPG recovery ranging from 93.88 to $94.92 \%$ in both combinations (ASD 16, and ADT 43) (Supplementary Table S2). Selfing was done in "positive" $\mathrm{BC}_{3} \mathrm{~F}_{1}$ hybrids with high $\mathrm{RPG}$ recovery to generate $\mathrm{BC}_{3} \mathrm{~F}_{2}$. In $\mathrm{BC}_{3} \mathrm{~F}_{2}$ generation, 11 plants in the ASD 16 background and 14 plants in the ADT 43 background were homozygous for targeted genes $(x a 5+x a 13+X a 21+$ Pi54 $)$ and targeted QTLs $(q S B R 7-1+q S B R 11-1+q S B R 11-2)$, and these were selfed to produce $\mathrm{BC}_{3} \mathrm{~F}_{3}$. These homozygous-improved gene pyramided lines at $\mathrm{BC}_{3} \mathrm{~F}_{3}$ generation were evaluated for physical expression of resistance against bacterial blight, blast, and sheath blight pathogens under greenhouse conditions. Out of 1,500 plants screened in both the crosses at field conditions, we found nine lines in ASD 16 background and 15 lines in ADT 43 background performing on par with the recurrent parents and, moreover, exhibiting a high level of resistance to all the three major diseases (Tables 2, 3 and Figures 2-5).

\section{Evaluation of Improved Pyramided Lines for Resistance to Bacterial Blight, Blast, and Sheath Blight Diseases}

\section{Bioassay for BB Resistance}

The resistant parent, IRBB60, possessing $x a 5$, xa13, and Xa21 exhibited a mean lesion length of $3.10 \pm 0.45$ with a disease reaction score of $0-1$ (highly resistant) against the isolate of 


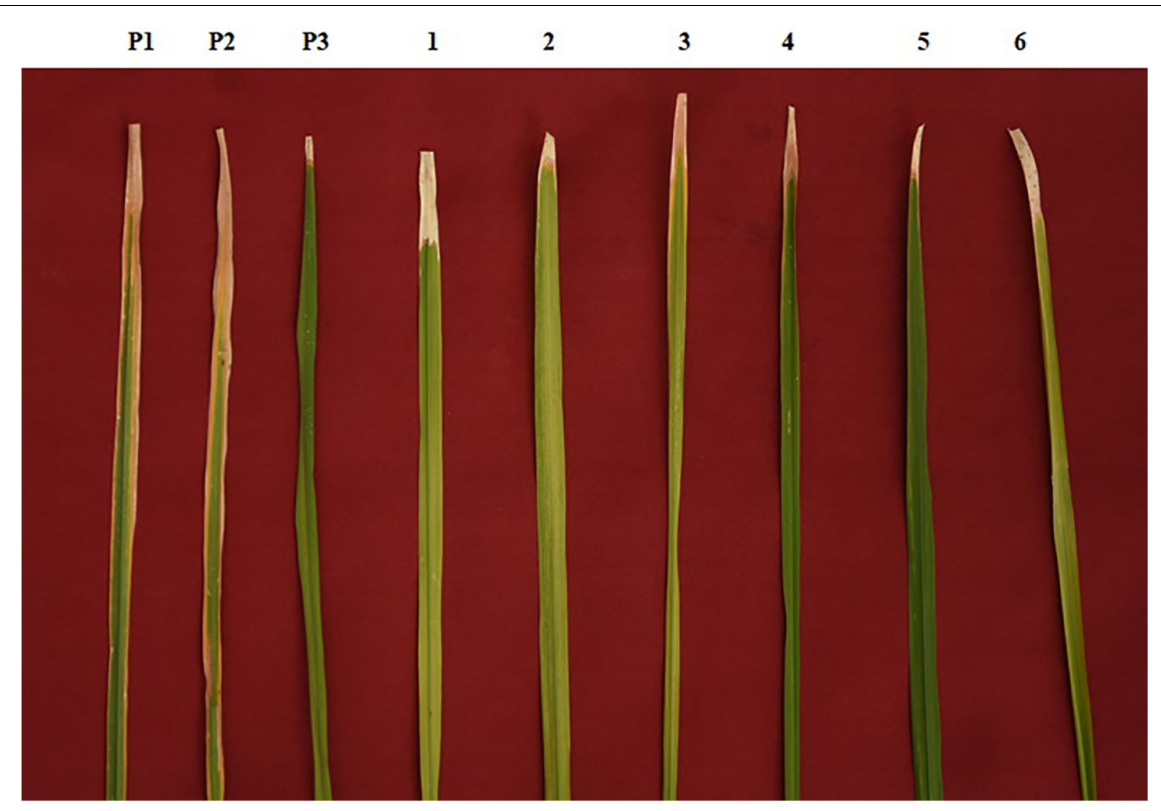

FIGURE 2 | Phenotypic screening of improved pyramided lines against DX-027 isolate of bacterial blight (BB). P1 - ASD 16, P2 - ADT 43, P3 - IRBB60; serially numbered 1, 2, 3, 4, 5, and 6 lines indicate improved pyramided lines of recurrent parents harboring xa5, xa13, and Xa21 genes.

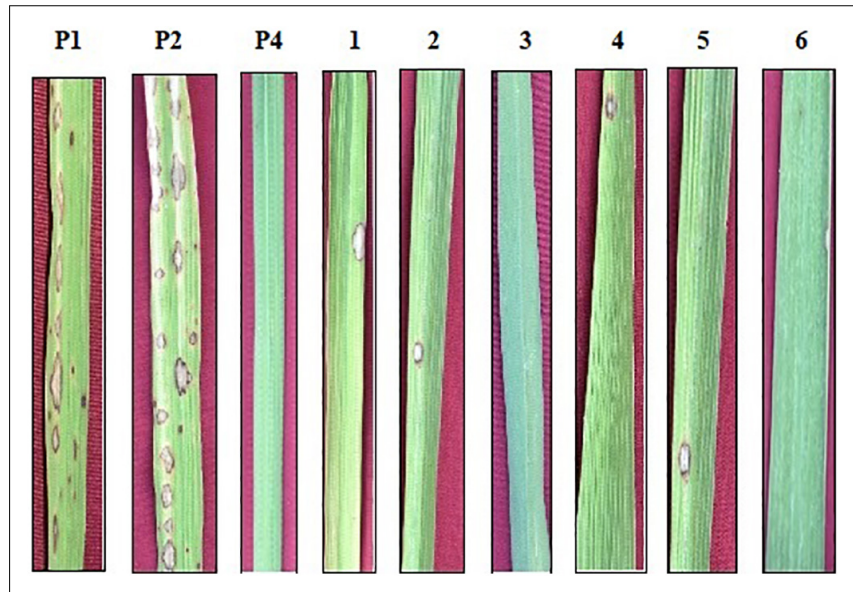

FIGURE 3 | Phenotypic screening of improved pyramided lines against IS (KUL)-6 isolate of Magnaporthe oryzae for leaf blast. P1 - ASD 16, P2 - ADT 43, P4 - Tetep; serially numbered 1, 2, 3, 4, 5, and 6 lines indicate improved pyramided lines of recurrent parents harboring the Pi54 gene.

DX-027. Similarly, the identified homozygous IPLs were also expressed, and the similar mean lesion length ranged from $3.15 \pm 0.56$ to $4.21 \pm 0.49$ with the same disease reaction score as the resistant parent. The two-gene pyramided lines $(x a 5+x a 13, x a 5+X a 21$, and $x a 13+X a 21)$ were shown a mean lesion length of $4.58 \pm 1.15$ with a score of $1-2$ (resistant). Evaluation of single-gene pyramided lines showed that Xa21 pyramided lines expressed a mean lesion length of $4.93 \pm 0.22$, $x a 13$ lines with $6.45 \pm 0.79$, and $x a 5$ lines with $6.85 \pm 0.64$ lesion lengths. This indicates that the lines that harbor the $X a 21$ component exhibited a high level of resistance than the other components in the disease reaction (data not shown), while the recurrent parents (ASD 16 and ADT 43) have shown an average lesion length of more than $15 \mathrm{~cm}$ with a disease reaction score of 9 (highly susceptible) for the same isolate of $\mathrm{BB}$ (Table 2 and Figure 2).

\section{Bioassay for Blast and Sheath Blight Resistance}

The resistant check, Tetep, possessing the Pi54 gene, exhibited a high level of resistance to leaf blast with no lesions observed on the leaf with a disease score of $0-1$ (highly resistant) against the isolate of IS (KUL)-6. Similarly, the selected IPLs harboring the Pi54 gene displayed small pin-point size brown specks to slightly elongated necrotic patches with a sporulating center with a disease score of 1-3 (highly resistant to resistant). While, the recurrent parents (ASD 16 and ADT 43) displayed spindleshaped lesions with brown margin with a disease reaction score of 9 (highly susceptible) (Table 2 and Figure 3 ). With regard to the sheath blight, Tetep possessing qSBR QTLs (qSBR7-1, qSBR11-1, and qSBR11-2) exhibited an RLH up to $28 \%$ with a disease score of 3 (moderately resistant). The susceptible checks, both ASD 16 and ADT 43, expressed an RLH of 78\% and 71\%, respectively, with disease score of 9 (highly susceptible). While the selected IPLs possessing qSBR7-1, qSBR11-1, and qSBR11-2 have expressed an RLH ranging from 28 to $45 \%$ with a disease score of 3 to 5 (moderately resistant to moderately susceptible) (Table 2 and Figure 4).

\section{Evaluation of Improved Pyramided Lines for Agro-Morphological and Quality Traits}

All the selected improved pyramided lines (nine lines in ASD 16 background and 15 lines in ADT 43 background) have similar 

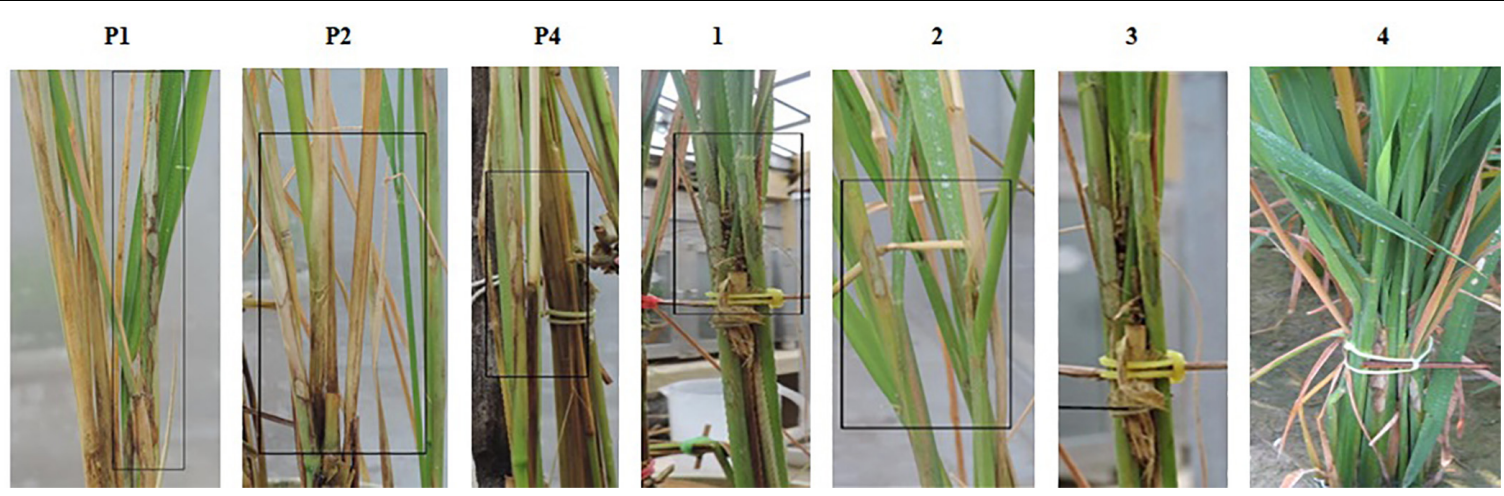

FIGURE 4 | Phenotypic screening of improved pyramided lines against sheath blight resistance. P1 - ASD 16, P2 - ADT 43, P4 - Tetep; serially numbered 1, 2, 3, and 4 lines indicate improved pyramided lines harboring qSBR7-1, qSBR11-1, and qSBR11-2 QTLS.
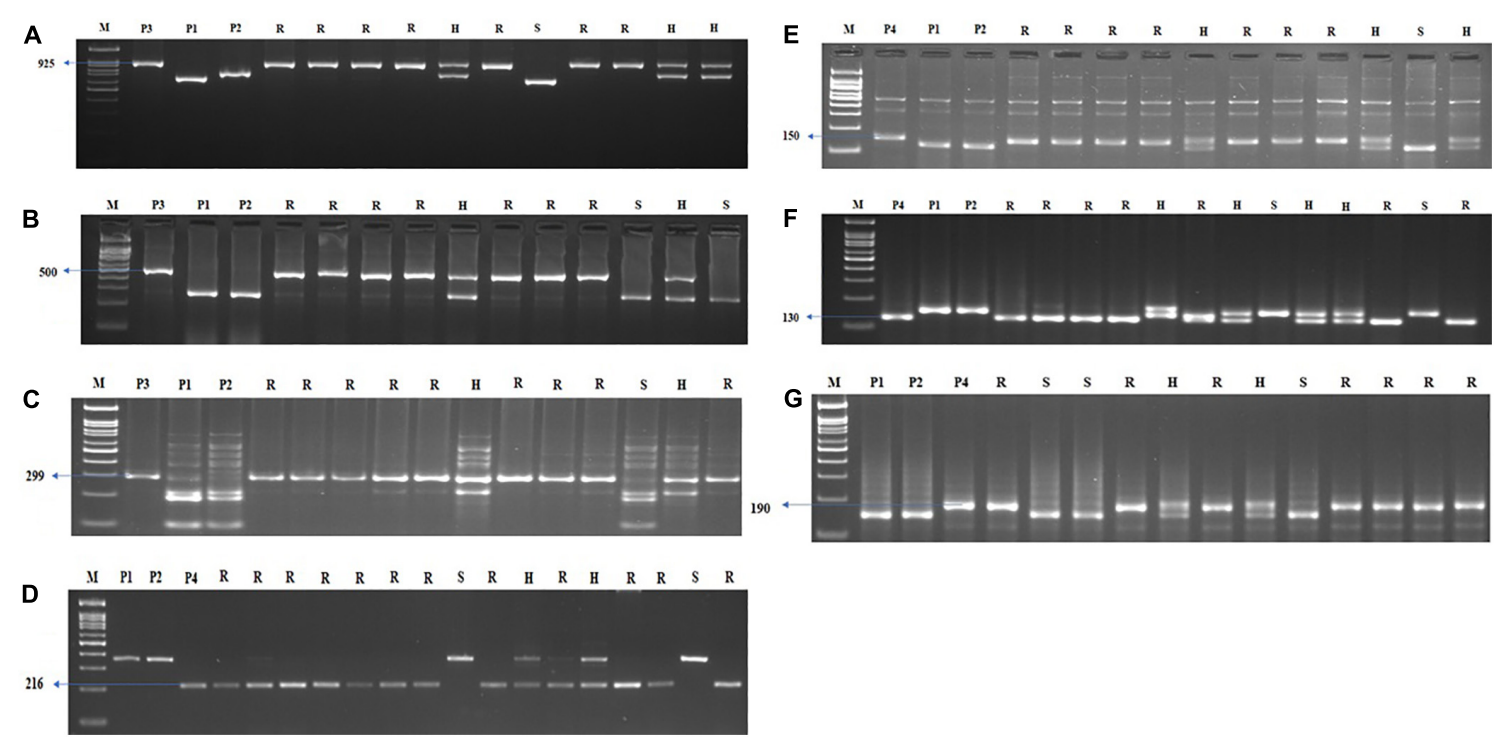

FIGURE 5 | Agarose gel electrophoresis images illustrating the presence of (A) Xa21, (B) xa13, (C) xa5, (D) Pi54, (E) qSBR11-2, (F) qSBR11-I, and (G) qSBR7-1 alleles. P1 - ASD 16, P2 - ADT 43, P3 - IRBB60, P4 - Tetep, M - 100-bp ladder, R, resistant; H, heterozygote; S, susceptible.

agro-morphological and quality traits as recurrent parents. Some promising lines have shown superior agro-morphological and quality traits and, moreover harboring BB, blast, and sheath blight resistance. Significant differences for plant height were observed among the few improved pyramided lines $\left(\mathrm{BC}_{3} \mathrm{~F}_{3}\right.$ generation), which were shown as taller than recurrent parents viz., ACM 18012, ACM 18245, ACM 18242, ACM 18243, ACM 18244, ACM 18013, and ACM 18014 (Table 3). The DFF for recurrent parents (ASD 16 and ADT 43) and donor parents (IRBB60 and Tetep) were 85 and 97 days, respectively. The selected improved pyramided lines at $\mathrm{BC}_{3} \mathrm{~F}_{3}$ generation harboring $x a 5+x a 13+X a 21+P i 54+q S B R 7-1+q S B R 11-1+q S B R 11-2$ also showed a similar range for DFF, i.e., 78-95 days. Two lines in the background of ASD 16 viz., ACM 18242 and ACM 18246 were significantly flowered $\sim 13-18$ days earlier than its respective recurrent parent, ASD 16 (Table 3 ). The mean values of recurrent parents for the number of grains per panicle ranged from $191 \pm 14.3$ to $201 \pm 11.2$. Several improved pyramided lines viz., ACM 18012, ACM 18245, ACM 18242, ACM 18243, ACM 18017, ACM 18016, ACM 18247, and ACM 18015 have shown significantly higher number of grains per panicle than both recurrent parents (Table 3). The mean 1,000-grain weight (g) of recurrent parents ranged from $15.6 \pm 0.4$ to $23.2 \pm 0.5$ for ADT 43 and ASD 16, respectively. The selected improved pyramided lines, ACM 18245, ACM 18244, ACM 18013, ACM 18016, ACM 18017, and ACM 18050 have shown significantly higher 1,000grain weight than both the recurrent parents ASD 16 and ADT 43 (Table 3). The HRR\% of recurrent parents ranged from 59.87 to 62.14 for ADT 43 and ASD 16, respectively, while the selected homozygous lines HRR\% are also on par with the recurrent parents and some of the lines have recovered more HRR\% than both the recurrent parents (Supplementary Table S3). Some of the promising lines, ACM 18012, ACM 18014, and ACM 18015 in the background of ADT 43 and ACM 18244, ACM 
TABLE 3 | Agro-morphological characters of selected improved pyramided lines at $\mathrm{BC}_{3} \mathrm{~F}_{3}$ generation.

\begin{tabular}{|c|c|c|c|c|c|c|c|c|c|c|}
\hline Genotype & $\begin{array}{l}\text { Days to } 50 \% \\
\text { flowering } \\
\text { (DFF) }\end{array}$ & $\begin{array}{l}\text { Plant height } \\
\text { (PH) (cm) }\end{array}$ & $\begin{array}{l}\text { Flag leaf } \\
\text { length (FL) } \\
(\mathrm{cm})\end{array}$ & $\begin{array}{c}\text { Flag leaf } \\
\text { width (FW) } \\
\text { (cm) }\end{array}$ & $\begin{array}{l}\text { Number of } \\
\text { productive } \\
\text { tillers per } \\
\text { plant (NPT) }\end{array}$ & $\begin{array}{c}\text { Panicle } \\
\text { length (PL) } \\
\text { (cm) }\end{array}$ & $\begin{array}{l}\text { Number of } \\
\text { grains per } \\
\text { panicle } \\
\text { (NGP) }\end{array}$ & $\begin{array}{c}\text { 1,000-Grain } \\
\text { weight } \\
(1,000-G W) \\
\text { (g) }\end{array}$ & L/B ratio & $\begin{array}{c}\text { Single plant } \\
\text { yield (SPY) } \\
\text { (g) }\end{array}$ \\
\hline ACM 18012 & 85 & $88.3 \pm 1.2$ & $32.5 \pm 0.6$ & $1.0 \pm 0.01$ & $18 \pm 2.1$ & $24.2 \pm 0.4$ & $199 \pm 4.5$ & $15.21 \pm 0.2$ & $3.71 \pm 0.02$ & $27.11 \pm 0.4$ \\
\hline ACM 18242 & 64 & $87.4 \pm 1.4$ & $29.3 \pm 0.4$ & $1.3 \pm 0.02$ & $16 \pm 1.4$ & $26.5 \pm 0.3$ & $205 \pm 9.7$ & $22.9 \pm 0.3$ & $2.32 \pm 0.04$ & $30.13 \pm 0.3$ \\
\hline ACM 18243 & 82 & $89.1 \pm 2.1$ & $28.4 \pm 0.4$ & $1.2 \pm 0.01$ & $20 \pm 3.2$ & $23.4 \pm 0.6$ & $207 \pm 8.1$ & $22.89 \pm 0.5$ & $2.43 \pm 0.01$ & $30.19 \pm 0.4$ \\
\hline ACM 18244 & 89 & $86.4 \pm 1.1$ & $28.8 \pm 0.5$ & $1.2 \pm 0.01$ & $17 \pm 2.1$ & $20.6 \pm 0.2$ & $202 \pm 9.4$ & $24.15 \pm 0.1$ & $2.59 \pm 0.02$ & $30.24 \pm 0.4$ \\
\hline ACM 18013 & 78 & $87.6 \pm 1.2$ & $33.1 \pm 0.4$ & $1.0 \pm 0.02$ & $14 \pm 3.2$ & $19.3 \pm 1.8$ & $194 \pm 12.6$ & $16.32 \pm 0.6$ & $3.68 \pm 0.05$ & $28.06 \pm 0.7$ \\
\hline ACM 18014 & 81 & $86.5 \pm 1.8$ & $32.5 \pm 0.3$ & $1.0 \pm 0.03$ & $16 \pm 1.4$ & $20.5 \pm 1.2$ & $188 \pm 10.3$ & $15.94 \pm 0.4$ & $3.61 \pm 0.03$ & $27.62 \pm 0.8$ \\
\hline ACM 18245 & 79 & $88.3 \pm 1.7$ & $29.4 \pm 0.4$ & $1.3 \pm 0.01$ & $14 \pm 2.4$ & $27.8 \pm 0.3$ & $212 \pm 11.2$ & $23.61 \pm 0.4$ & $2.62 \pm 0.02$ & $29.65 \pm 0.4$ \\
\hline ACM 18246 & 65 & $83.8 \pm 2.3$ & $28.7 \pm 0.1$ & $1.2 \pm 0.02$ & $16 \pm 2.1$ & $24.3 \pm 1.1$ & $201 \pm 6.8$ & $22.78 \pm 0.5$ & $2.32 \pm 0.01$ & $27.19 \pm 1.1$ \\
\hline ACM 18247 & 88 & $78.8 \pm 3.4$ & $29.3 \pm 0.4$ & $1.2 \pm 0.03$ & $14 \pm 3.2$ & $21.2 \pm 0.6$ & $213 \pm 14.1$ & $22.19 \pm 0.1$ & $2.18 \pm 0.01$ & $29.89 \pm 0.3$ \\
\hline ACM 18015 & 83 & $79.7 \pm 3.8$ & $33.2 \pm 0.3$ & $1.0 \pm 0.01$ & $15 \pm 1.5$ & $20.8 \pm 1.4$ & $198 \pm 12.2$ & $15.29 \pm 0.4$ & $3.78 \pm 0.05$ & $28.18 \pm 0.2$ \\
\hline ACM 18016 & 84 & $85.4 \pm 2.4$ & $32.8 \pm 0.6$ & $0.9 \pm 0.01$ & $15 \pm 2.1$ & $21.5 \pm 0.5$ & $198 \pm 13.4$ & $15.23 \pm 0.6$ & $3.91 \pm 0.03$ & $27.95 \pm 1.2$ \\
\hline ACM 18017 & 81 & $88.3 \pm 1.3$ & $33.1 \pm 0.2$ & $0.9 \pm 0.02$ & $16 \pm 2.3$ & $23.8 \pm 0.8$ & $192 \pm 11.9$ & $16.65 \pm 1.2$ & $3.89 \pm 0.08$ & $28.24 \pm 0.5$ \\
\hline ACM 18248 & 85 & $86.2 \pm 1.7$ & $28.6 \pm 0.5$ & $1.2 \pm 0.02$ & $14 \pm 2.8$ & $23.7 \pm 0.5$ & $188 \pm 16.6$ & $24.08 \pm 0.6$ & $2.32 \pm 0.05$ & $29.85 \pm 0.8$ \\
\hline ACM 18018 & 85 & $81.5 \pm 2.5$ & $33.2 \pm 0.2$ & $0.9 \pm 0.01$ & $18 \pm 1.2$ & $18.3 \pm 1.8$ & $185 \pm 6.5$ & $15.27 \pm 0.4$ & $3.81 \pm 0.04$ & $27.49 \pm 1.1$ \\
\hline ACM 18249 & 85 & $81.6 \pm 2.6$ & $29.1 \pm 0.2$ & $1.1 \pm 0.06$ & $16 \pm 1.4$ & $24.1 \pm 1.1$ & $194 \pm 8.5$ & $22.34 \pm 0.1$ & $2.24 \pm 0.04$ & $29.71 \pm 0.4$ \\
\hline ACM 18250 & 79 & $79.7 \pm 3.9$ & $29.2 \pm 0.5$ & $1.2 \pm 0.03$ & $16 \pm 2.1$ & $23.4 \pm 0.7$ & $197 \pm 8.1$ & $22.56 \pm 0.8$ & $2.14 \pm 0.06$ & $27.15 \pm 1.1$ \\
\hline ACM 18019 & 83 & $89.4 \pm 0.8$ & $32.8 \pm 0.3$ & $0.9 \pm 0.02$ & $14 \pm 2.4$ & $23.8 \pm 0.4$ & $195 \pm 12.9$ & $15.15 \pm 1.1$ & $3.68 \pm 0.04$ & $28.23 \pm 0.7$ \\
\hline ACM 18020 & 81 & $81.3 \pm 3.1$ & $33.1 \pm 0.1$ & $1.0 \pm 0.01$ & $17 \pm 3.3$ & $25.9 \pm 0.3$ & $196 \pm 4.8$ & $15.87 \pm 1.3$ & $3.72 \pm 0.06$ & $27.48 \pm 0.5$ \\
\hline ACM 18021 & 82 & $85.3 \pm 1.1$ & $32.4 \pm 0.2$ & $1.0 \pm 0.01$ & $17 \pm 1.2$ & $24.2 \pm 0.4$ & $195 \pm 3.4$ & $15.52 \pm 1.1$ & $3.69 \pm 0.02$ & $26.2 \pm 1.1$ \\
\hline ACM 18022 & 83 & $84.7 \pm 1.9$ & $33.2 \pm 0.1$ & $0.9 \pm 0.01$ & $16 \pm 1.6$ & $24.6 \pm 0.2$ & $182 \pm 4.7$ & $15.23 \pm 0.4$ & $3.69 \pm 0.05$ & $25.8 \pm 0.4$ \\
\hline ACM 18023 & 78 & $82.5 \pm 2.3$ & $32.7 \pm 0.3$ & $0.9 \pm 0.03$ & $17 \pm 1.2$ & $25.1 \pm 0.3$ & $189 \pm 2.1$ & $15.29 \pm 0.8$ & $3.70 \pm 0.02$ & $26.4 \pm 0.2$ \\
\hline ASD 16 & 86 & $84.4 \pm 3.1$ & $29.3 \pm 0.4$ & $1.2 \pm 0.05$ & $19 \pm 2.6$ & $22.5 \pm 0.6$ & $201 \pm 11.2$ & $23.2 \pm 0.5$ & $2.08 \pm 0.01$ & $29.2 \pm 0.2$ \\
\hline ADT 43 & 85 & $85.2 \pm 2.4$ & $32.7 \pm 0.4$ & $1.0 \pm 0.03$ & $18 \pm 1.3$ & $24.3 \pm 0.8$ & $191 \pm 14.3$ & $15.6 \pm 0.4$ & $3.69 \pm 0.07$ & $27.6 \pm 0.4$ \\
\hline IRBB60 & 91 & $87.7 \pm 4.8$ & $31.1 \pm 0.4$ & $1.1 \pm 0.02$ & $15 \pm 2.5$ & $22.83 \pm 2.5$ & $148 \pm 7.8$ & $18.76 \pm 0.6$ & $3.34 \pm 0.04$ & $25.32 \pm 0.3$ \\
\hline Tetep & 97 & $123.2 \pm 5.8$ & $35.5 \pm 0.3$ & $0.85 \pm 0.05$ & $17 \pm 2.2$ & $27.13 \pm 3.1$ & $153 \pm 19.7$ & $19.15 \pm 1.2$ & $3.43 \pm 0.05$ & $26.15 \pm 0.9$ \\
\hline SE & 1.199 & 0.646 & 0.392 & 0.0282 & 0.312 & 0.471 & 1.594 & 0.762 & 0.142 & 0.296 \\
\hline CD (5\%) & 1.74 & 1.62 & 0.6 & 0.05 & 1.34 & 0.75 & 3.81 & 0.54 & 0.02 & 0.36 \\
\hline
\end{tabular}

18245, and ACM 18249 in the background of ASD 16 have shown superior quality traits than both the recurrent parents (Supplementary Table S3).

\section{Cluster Analysis}

The coefficient of genetic distance on 10 morphological traits of 24 pyramided lines and four parents revealed that all the pyramided lines were very similar with their respective recurrent parent. It was observed that two solitary clusters were formed, one with Tetep alone and another with improved pyramided lines, IRBB60 and recurrent parents (ASD 16, and ADT 43). Cluster II was subdivided into two clusters, i.e., one subcluster with ASD 16 and its respective pyramided lines, another subcluster with IRBB60, ADT 43 parent, and its respective pyramided lines. Obviously, all the improved pyramided lines were being clubbed into their respective recurrent parent cluster (Figure 6).

\section{DISCUSSION}

More than half of the population of the globe is consuming rice to meet their dietary requirements. The demand for rice production is increasing, and many studies have reported that global rice production need to be doubled to meet the demands of the growing population (Ray et al., 2013). Besides the growing population, many biotic and abiotic stresses are affecting both yield and quality of rice crop. To address these constraints and to increase rice production, development of high-yielding cultivars enriched with resistant genes will enhance the yield as well as host-plant resistance. Conventional backcross method is the primary approach to develop resistant cultivars for single gene resistance, but phenotypic selection is a difficult and time-consuming process when multiple genes are involved in disease resistance (Crossa et al., 2017). The use of markerassisted selection with stringent phenotypic selection enhances the efficiency and precision of breeding program for developing multiple disease-resistant varieties.

Marker-assisted backcross breeding (MABB) is a fastidious method for introgression of two or more targeted genes in the elite cultivars for improving the deficient trait. The prime aim of MABB is to transfer the targeted genes into the background of elite cultivars and to recover the RP genome as quickly as possible with a limited number of backcrosses. MABB also focuses on gradual reduction of donor parent genome as much as possible to avoid the undesirable effects on agronomical, yield, and quality 


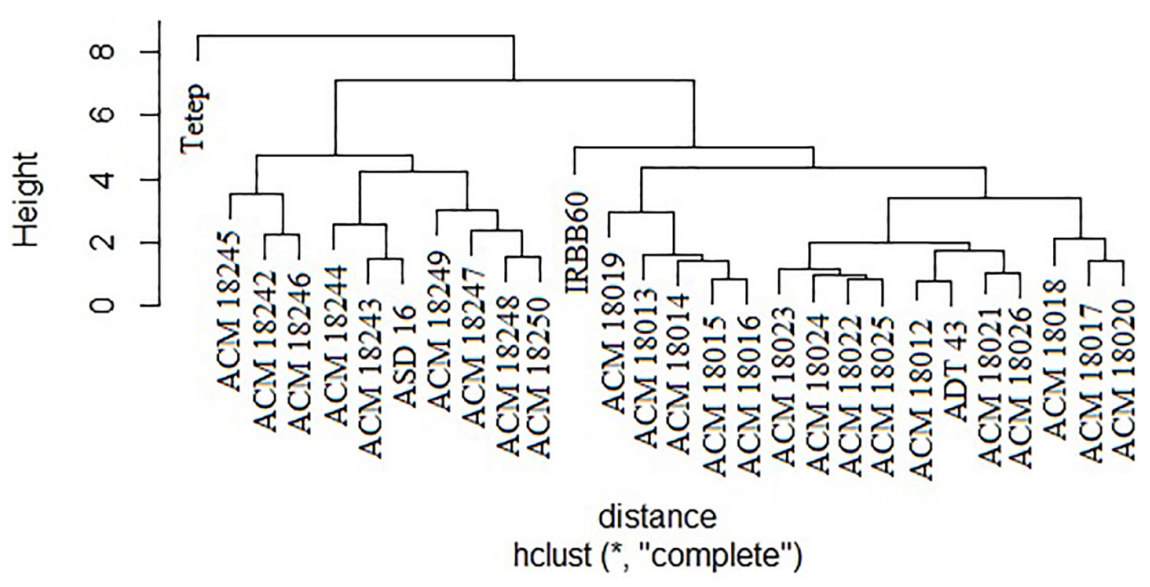

FIGURE 6 | Clustering of 24 selected improved pyramided lines based on 10 morphological characters. *Euclidean distance.

traits. The recurrent parents (ASD 16 and ADT 43) in this study are the popular and high-yielding cultivars of South India. Bacterial blight, blast, and sheath blight diseases are the major diseases of South India causing huge losses to the crop.

Many studies have focused on developing resistance to one or two diseases, as developing resistance to more than two diseases is a complex and time-consuming process. There are a few reports on developing multiple disease-resistant cultivars. Singh et al. (2012) introgressed blast and sheath blight resistance genes/QTLs in the background of Improved Pusa Basmati 1, harboring xa13, and Xa21 genes. Das and Rao (2015) introgressed blast (Pi2 and Pi9), submergence (Sub1), gall midge (Gm1, Gm4), and salinity (Saltol1) genes/QTLs in the background of Improved Lalat harboring Xa4, xa5, xa13, and Xa21. Arunakumari et al. (2016) has introgressed bacterial blight and blast resistance genes into the popular cultivar MTU 1010. As a part of sustainable management, we have planned and executed the introgression of BB ( $x a 5, x a 13$, and Xa21), blast (Pi54), and sheath blight (qSBR7-1, qSBR11-1, and $q S B R 11-2)$ resistance genes/QTLs in the backgrounds of ASD 16 and ADT 43 for achieving multiple disease resistance and to offer IPL to farmers.

In this study, background screening with polymorphic SSR markers was used to recover the maximum percentage of RPG in early generations. At $\mathrm{BC}_{3} \mathrm{~F}_{1}$, we have achieved $\mathrm{RPG}$ recovery in both ASD 16 and ADT 43 backgrounds. The background recovery rate in this study was at par with the theoretical recovery rate. We have observed inheritance of some unfavorable characters (plant height and grain qualities) along with favorable resistant traits while introgressing genes/QTLs from Tetep. Nevertheless, we have identified superior segregates with minimal residual effect from the Tetep genome by assessing greater population size (1,500 plants in both crosses). Sundaram et al. (2008), reported that introgression of Xa21, xa13, and $x a 5$ genes from SS1113 exercises a "pull" through inheritance of undesirable loci from a donor segment. Singh et al. (2015) introgressed $q S B R 7-1, q S B R 11-1$, and $q S B R 11-2$ into Pusa $6 \mathrm{~B}$, but they have not observed the inheritance of undesirable loci from Tetep. The observed undesirable effects of Tetep on the agronomic characters might be due to the linkage drag or environmental influence on agronomic characters.

The agronomic performance of 24 selected improved pyramided lines of both ASD 16 and ADT 43 backgrounds at $\mathrm{BC}_{3} \mathrm{~F}_{3}$ generation revealed that most of the agro-morphological traits were on par with their recurrent parents (ASD 16 and ADT 43) and also showed durable resistance to BB, blast, and sheath blight diseases. The higher yield and superior quality traits of improved pyramided lines were probably due to the inheritance of yield contributing traits from the recurrent parents. The yield, agro-morphological, and quality traits were normally controlled by polygenes, and these are distributed throughout the genome. Employment of a greater number of background markers accelerated the recovery of RPG in the early generations. Cluster analysis of selected pyramided lines and parents based on 10 morphological characters revealed that all the selected pyramided lines were clustered in their recurrent parent's cluster. This is due to the similar morphological characters of pyramided lines with their recurrent parent's. Similar results were also obtained by Pradhan et al. (2015) and Hsu et al. (2020), while introgressing BB resistance genes, which supports the present study results.

The homozygous improved pyramided lines $\left(\mathrm{BC}_{3} \mathrm{~F}_{3}\right.$ generation) harboring $x a 5+x a 13+X a 21+P i 54+q S B R 7-1+$ qSBR11-1 + qSBR11-2 were assessed for physical resistance under greenhouse conditions. The results of bioassays suggest that pyramiding three BB-resistant genes exhibited higher resistance levels than the lines with one or two genes. In addition, the present study results also reveal that the gene combination with $\mathrm{Xa21}$ component expressed a shorter lesion length than the remaining gene combinations. These results were consistent with the results of previous studies (Peng et al., 2015; Pradhan et al., 2015; Ramalingam et al., 2017; Yugander et al., 2018; Hsu et al., 2020). The improved pyramided lines harboring the Pi54 gene and ShB-resistant QTLs have expressed a similar disease reaction as donor parent, Tetep. This is due to the transfer of resistant alleles from the donor parent, which was confirmed by 
functional/linked molecular markers as well as phenotypic screening methods.

The field evaluation of improved pyramided lines at $\mathrm{BC}_{3} \mathrm{~F}_{3}$ generation demonstrated that the candidate lines of both recurrent parents had equivalent expression of yield, agromorphological, and quality traits and, more importantly, with pyramided genes for $\mathrm{BB}$, blast, and sheath blight. The higher levels of resistance to multiple diseases, without any yield penalty, is an integrated approach of genotypic and phenotypic selection methods. Developing broad-spectrum resistance to multiple diseases is a challenging task due to rich diversity of agro-climatic conditions in India along with the existence of genetically distinct virulent strains of different plant pathogens. Pyramiding of multiple or effective resistant genes/QTLs for different biotic stresses can contribute broad-spectrum and durable resistance to multiple diseases to the rice regions in India. The present study results prove that $\mathrm{MABB}$ is an effective tool for pyramiding major genes/QTLs to obtain improved plant lines in a quick time frame.

Introgression of $\mathrm{BB}$ resistance genes from IRBB60, blast and sheath blight resistance genes/QTLs from Tetep into the commercial cultivars is a significant achievement for obtaining durable resistance to multiple diseases. Introgression of identified effective resistance genes from the wild relatives or landraces into the commercial cultivars gradually improves the host-plant resistance to different biotic and abiotic stresses for attaining food and nutritional security. In conclusion, we have introgressed $x a 5, x a 13, X a 21, P i 54$, and qSBR QTLs (qSBR7-1, qSBR11-1, and $q S B R 11-2)$ in the backgrounds of ASD 16 and ADT 43 to improve host-plant resistance to $\mathrm{BB}$, blast, and sheath blight diseases. The improved pyramided lines can be further tested in multilocational trails and could be released as improved variety or used as a potential donor in hybridization programs for developing multiple disease-resistant cultivars in rice.

\section{REFERENCES}

Arunakumari, K., Durgarani, C. V., Satturu, V., Sarikonda, K. R., Chittoor, P. D. R., and Vutukuri, B. (2016). Marker-assisted pyramiding of genes conferring resistance against bacterial blight and blast diseases into Indian rice variety MTU1010. Rice Sci. 23, 306-316. doi: 10.1016/j.rsci.2016.04.005

Babujee, L., and Gnanamanickam, S. S. (2000). Molecular tools for characterization of rice blast pathogen (Magnaporthe grisea) population and molecular markerassisted breeding for disease resistance. Curr. Sci. 78, 248-257.

Blair, M. W., Garris, A. J., Iyer, A. S., Chapman, B., Kresovich, S., and McCouch, S. R. (2003). High resolution genetic mapping and candidate gene identification at the xa5 locus for bacterial blight resistance in rice (Oryza sativa L.). Theor. Appl. Genet. 107, 62-73. doi: 10.1007/s00122-003-1231-2

Channamallikarjuna, V., Sonah, H., Prasad, M., Rao, G. J. N., Chand, S., and Upreti, H. C. (2010). Identification of major quantitative trait loci $q S B R 11-1$ for sheath blight resistance in rice. Mol. Breed. 25, 155-166. doi: 10.1007/s11032-0099316-5

Chen, S., Wang, C., Yang, J., Chen, B., Wang, W., and Su, J. (2020). Identification of the novel bacterial blight resistance gene Xa46(t) by mapping and expression analysis of the rice mutant H120. Sci. Rep. 10:12642. doi: 10.1038/s41598-02069639-y

Chu, Z., Fu, B., Yang, H., Xu, C., Li, Z., and Sanchez, A. (2006). Targeting xa13, a recessive gene for bacterial blight resistance in rice. Theor. Appl. Genet. 112, 455-461. doi: 10.1007/s00122-005-0145-6

Crossa, J., Pérez-Rodríguez, P., Cuevas, J., Montesinos-López, O., Jarquín, D., and de los Campos, G. (2017). Genomic selection in plant breeding: methods,

\section{DATA AVAILABILITY STATEMENT}

The original contributions presented in the study are included in the article/Supplementary Material, further inquiries can be directed to the corresponding author.

\section{AUTHOR CONTRIBUTIONS}

JR designed the experiment. ChR, PS, RS, VV, and TC were involved in the experiments. JR, ChR, RS, and PS developed the improved pyramided lines. SV and MA were involved in a part of the experiment. JR, ChR, VV, and AR were involved in the screening of improved pyramided lines. JR, SA, and CV were involved in the revision of the final version of the manuscript. $\mathrm{JR}$ and all the authors prepared and approved the final version of the manuscript.

\section{FUNDING}

This study was financially supported by DBT under a ATGC research grant ( 127-SP32889), New Delhi, India. The first author acknowledges the DBT for providing assistance for research programme at Tamil Nadu Agricultural University, Coimbatore, part of which is reported in this study.

\section{SUPPLEMENTARY MATERIAL}

The Supplementary Material for this article can be found online at: https://www.frontiersin.org/articles/10.3389/fpls.2020. 591457/full\#supplementary-material

models, and perspectives. Trends Plant Sci. 22, 961-975. doi: 10.1016/j.tplants. 2017.08.011

Das, G., and Rao, G. J. N. (2015). Molecular marker assisted gene stacking for biotic and abiotic stress resistance genes in an elite rice cultivar. Front. Plant Sci. 6:698. doi: $10.3389 /$ fpls.2015.00698

Gupta, S. K., Rai, A. K., Kanwar, S. S., Chand, D., Singh, N. K., and Sharma, T. R. (2012). The single functional blast resistance gene Pi54 activates a complex defence mechanism in rice. J. Exp. Bot. 63, 757-772. doi: 10.1093/jxb/err297

Hsu, Y. C., Chiu, C. H., Yap, R., Tseng, Y. C., and Wu, Y. P. (2020). Pyramiding bacterial blight resistance genes in tainung82 for broad-spectrum resistance using marker-assisted selection. Int. J. Mol. Sci. 21:1281. doi: 10.3390/ ijms 21041281

Huang, N., Angeles, E. R., Domingo, J., Magpantay, G., Singh, S., and Zhang, G. (1997). Pyramiding of bacterial blight resistance genes in rice: marker-assisted selection using RFLP and PCR. Theor. Appl. Genet. 95, 313-320. doi: 10.1007/ s001220050565

International Rice Research Institute [IRRI] (2002). Standard Evaluation System (SES). Los Baños: IRRI.

Iyer-Pascuzzi, A. S., and McCouch, S. R. (2007). Functional markers for xa5mediated resistance in rice (Oryza sativa L.). Mol. Breed. 19, 291-296. doi: 10.1007/s11032-006-9055-9

Kauffman, H. E., Reddy, A. P. K., Hsieh, S. P. Y., and Merca, S. D. (1973). An improved technique for evaluating resistance of rice varieties to Xanthomonas oryzae. Plant Dis. Rep. 57, 537-541.

Khush, G. S. (2013). Strategies for increasing the yield potential of cereals: case of rice as an example. Plant Breed. 132, 433-436. doi: 10.1111/pbr.1991 
Kumar, P. N., Sujatha, K., Laha, G. S., Rao, K. S., Mishra, B., and Viraktamath, B. C. (2012). Identification and fine-mapping of Xa33, a novel gene for resistance to Xanthomonas oryzae pv. oryzae. Phytopathology 102, 222-228. doi: 10.1094/ Phyto-03-11-0075

Lee, K. S., Rasabandith, S., Angeles, E. R., and Khush, G. S. (2003). Inheritance of resistance to bacterial blight in 21 cultivars of rice. Phytopathology 93:147. doi: 10.1094/phyto.2003.93.2.147

Molla, K. A., Karmakar, S., Molla, J., Bajaj, P., Varshney, R. K., and Datta, S. K. (2020). Understanding sheath blight resistance in rice: the road behind and the road ahead. Plant Biotechnol. J. 18, 895-915. doi: 10.1111/pbi.13312

Nguyen, H. T., Vu, Q. H., Van Mai, T., Nguyen, T. T., Vu, L. D., and Nguyen, T. T. (2018). Marker-assisted selection of Xa21 conferring resistance to bacterial leaf blight in Indica rice cultivar LT2. Rice Sci. 25, 52-56. doi: 10.1016/j.rsci.2017. 08.004

Peng, H., Chen, Z., Fang, Z., Zhou, J., Xia, Z., and Gao, L. (2015). Rice Xa21 primed genes and pathways that are critical for combating bacterial blight infection. Sci. Rep. 5, 1-12. doi: 10.1038/srep 12165

Pradhan, S. K., Nayak, D. K., Mohanty, S., Behera, L., Barik, S. R., and Pandit, E. (2015). Pyramiding of three bacterial blight resistance genes for broad-spectrum resistance in deepwater rice variety, Jalmagna. Rice 8:19. doi: 10.1186/s12284015-0051-8

R Core Team (2013). R: A Language and Environment for Statistical Computing. Vienna: R Foundation for Statistical Computing.

Ramalingam, J., Savitha, P., Alagarasan, G., Saraswathi, R., and Chandrababu, R. (2017). Functional marker-assisted improvement of stable cytoplasmic male sterile lines of rice for bacterial blight resistance. Front. Plant Sci. 8:1131. doi: 10.3389/fpls.2017.01131

Ramkumar, G., Srinivasarao, K., Mohan, K. M., Sudarshan, I., Sivaranjani, A. K. P., and Gopalakrishna, K. (2011). Development and validation of functional marker targeting an InDel in the major rice blast disease resistance gene Pi54 (Pikh). Mol. Breed. 27, 129-135. doi: 10.1007/s11032-010-9538-6

Ray, D. K., Mueller, N. D., West, P. C., and Foley, J. A. (2013). Yield trends are insufficient to double global crop production by 2050. PLoS One 8:e66428. doi: 10.1371/journal.pone.0066428

Ronald, P. C., Albano, B., Tabien, R., Abenesl, L., Wu, K., McCouch, S. R., et al. (1992). Genetic and physical analysis of the rice bacterial blight disease resistance locus, Xa21. Mol. Genet. Genom. 236, 113-120. doi: 10.1007/ bf00279649

Savary, S., Willocquet, L., and Teng, P. S. (1997). Modelling sheath blight epidemics on rice tillers. Agric. Syst. 55, 359-384. doi: 10.1016/s0308-521x(97)00014-0

Sharma, T. R., Madhav, M. S., Singh, B. K., Shanker, P., Jana, T. K., and Dalal, V. (2005). High-resolution mapping, cloning and molecular characterization of the Pi-kh gene of rice, which confers resistance to Magnaporthe grisea. Mol. Genet. Genom. 274, 569-578. doi: 10.1007/s00438-005-0035-2

Sharma, T. R., Rai, A. K., Gupta, S. K., Vijayan, J., Devanna, B. N., and Ray, S. (2012). Rice blast management through host-plant resistance: retrospect and prospects. Agric. Res. 1, 37-52. doi: 10.1007/s40003-011-0003-5

Singh, A. K., Gopalakrishnan, S., Singh, V. P., Prabhu, K. V., Mohapatra, T., and Singh, N. K. (2011). Marker assisted selection: a paradigm shift in Basmati breeding. Indian J. Genet. Plant Breed. 71, 120-128.

Singh, A. K., Singh, V. K., Singh, A., Ellur, R. K., Pandian, R. T. P., and Gopala Krishnan, S. (2015). Introgression of multiple disease resistance into a maintainer of Basmati rice CMS line by marker-assisted backcross breeding. Euphytica 203, 97-107. doi: 10.1007/s10681-014-1267-1

Singh, A. K., Singh, V. K., Singh, S. P., Pandian, R. T. P., Ellur, R. K., and Singh, D. (2012). Molecular breeding for the development of multiple disease resistance in Basmati rice. AoB Plants 2012:pls029. doi: 10.1093/aobpla/pls029

Singh, P., Mazumdar, P., Harikrishna, J. A., and Babu, S. (2019). Sheath blight of rice: a review and identification of priorities for future research. Planta 250, 1387-1407. doi: 10.1007/s00425-019-03246-8

Song, W. Y., Wang, G. L., Chen, L. L., Kim, H. S., Pi, L. Y., and Holsten, T. (1995). A receptor kinase-like protein encoded by the rice disease resistance gene, Xa21. Science 270, 1804-1806. doi: 10.1126/science.270.5243.1804

Sundaram, R. M., Vishnupriya, M. R., Biradar, S. K., Laha, G. S., Reddy, G. A., and Rani, N. S. (2008). Marker-assisted introgression of bacterial blight resistance in Samba Mahsuri, an elite indica rice variety. Euphytica 160, 411-422. doi: 10.1007/s10681-007-9564-6

Thakur, S., Singh, P. K., Das, A., Rathour, R., Variar, M., and Prashanthi, S. K. (2015). Extensive sequence variation in rice blast resistance gene Pi54 makes it broad spectrum in nature. Front. Plant Sci. 6:345. doi: 10.3389/fpls.2015.00345

Varghese, Y. A., Knaak, C., Sethuraj, M. R., and Ecke, W. (1997). Evaluation of random amplified polymorphic DNA (RAPD) markers in Hevea brasiliensis. Plant Breed. 116, 47-52. doi: 10.1111/j.1439-0523

Wang, Y., Pinson, S. R. M., Fjellstrom, R. G., and Tabien, R. E. (2012). Phenotypic gain from introgression of two QTL, $q S B 9-2$ and $q S B 12-1$, for rice sheath blight resistance. Mol. Breed. 30, 293-303. doi: 10.1007/s11032-011-9 619-1

Yadav, S., Anuradha, G., Kumar, R. R., Vemireddy, L. R., Sudhakar, R., and Donempudi, K. (2015). Identification of QTLs and possible candidate genes conferring sheath blight resistance in rice (Oryza sativa L.). Springerplus 4:175. doi: 10.1186/s40064-015-0954-2

Yugander, A., Sundaram, R. M., Singh, K., Ladhalakshmi, D., Subba Rao, L. V., and Madhav, M. S. (2018). Incorporation of the novel bacterial blight resistance gene Xa38 into the genetic background of elite rice variety Improved Samba Mahsuri. PLoS One 13:e0198260. doi: 10.1371/journal.pone.0198260

Zhang, G., Angeles, E. R., Abenes, M. L. P., Khush, G. S., and Huang, N. (1996). RAPD and RFLP mapping of the bacterial blight resistance gene $x a-13$ in rice. Theor. Appl. Genet. 93, 65-70. doi: 10.1007/BF00225728

Zhang, M., Wang, S., and Yuan, M. (2019). An update on molecular mechanism of disease resistance genes and their application for genetic improvement of rice. Mol. Breed. 39:154. doi: 10.1007/s11032-019-1056-6

Conflict of Interest: The authors declare that the research was conducted in the absence of any commercial or financial relationships that could be construed as a potential conflict of interest.

Copyright (C) 2020 Ramalingam, Raveendra, Savitha, Vidya, Chaithra, Velprabakaran, Saraswathi, Ramanathan, Arumugam Pillai, Arumugachamy and Vanniarajan. This is an open-access article distributed under the terms of the Creative Commons Attribution License (CC BY). The use, distribution or reproduction in other forums is permitted, provided the original author(s) and the copyright owner(s) are credited and that the original publication in this journal is cited, in accordance with accepted academic practice. No use, distribution or reproduction is permitted which does not comply with these terms. 